\title{
Pengenalan dan pengendalian hama dan penyakit utama tanaman cabai di Desa Sungai Geringging Kecamatan Kampar Kiri Kabupaten Kampar
}

\author{
Hafiz Fauzana*, Rusli Rustam, Nelvia, Yetti Elfina, Wardati, \& Murniati
}

Universitas Riau

*fauzana_hafiz@yahoo.co.id

\begin{abstract}
Abstrak. Tanaman cabai merupakan salah satu komoditas hortikultura yang mempunyai nilai ekonomis dan banyak ditanam di Desa Sungai Geringging Kecamatan Kampar Kiri Kabupaten Kampar. Kendala utama dalam pencapaian kuantitas dan kualitas produksi cabai adalah serangan hama dan penyakit. Pengabdian ini bertujuan untuk memberikan pengetahuan kepada para petani cabai di Desa Sungai Geringging tentang jenis hama dan penyakit yang menyerang cabai, gejala serangan, dan metoda pengendaliannya. Metoda penyuluhan yang dilakukan metoda penyuluhan dan demonstrasi. Penyuluhan berupa penyajian di dalam ruangan menggunakan alat bantu LCD dan infocus serta demonstraksi yaitu memperagakan jenis hama dan penyakit yang menyerang cabai, gejala serangannya, diskusi dan tanya jawab tentang hama dan penyakit tanaman cabai serta teknik pengendaliannya. Program pengabdian dalam bentuk penyuluhan dan demonstrasi sangat direspon baik oleh petani cabai, penyuluhan dan demostrasi dengan materi pengenalan dan pengendalian hama cabai belum pernah mereka terima, dalam budidaya tanaman cabai kendala yang sering dihadapi petani adalah masalah hama dan penyakitnya sehingga sangat direspon baik petani.
\end{abstract}

Kata Kunci : cabai (Capsicum annum), hama dan penyakit, pengenalan, pengendalian

\begin{abstract}
Chili plants are one of the horticultural commodities that have economic value and are widely planted in Sungai Geringging Village, Kampar Kiri District, Kampar Regency. The main obstacle in achieving the quantity and quality of chili production is the attack of pests and diseases. This service aims to provide knowledge to chili farmers in Sungai Geringging Village about the types of pest and disease that attack chilies, symptoms of attack, and methods of control. The extension methods are lectures, questions and answers, discussions, demonstrations and practices with regard to chili plants. Extension is in the form of indoor presentation using LCD and in-focus tools by demonstrating the types of pest and disease that attack chilies and their attack symptoms, discussion and question and answer about pests and diseases of chili plants and their control techniques. Service programs in the form of counseling and demonstrations have been very well responded by chili farmers, counseling and demonstrations with material on how to introduce and control chili pests have never been received, plus in the cultivation of chili plants the obstacles that are often faced by farmers are problems with pests and diseases therefore participating farmers pay closer attention.
\end{abstract}

Keywords: chili (Capsicum annum), pest and disease, introduction, control

To cite this article: Fauzana, H., R. Rustam., Nelvia., Y. Elfina., Wardat.i, \& Murniati. 2020. Pengenalan dan pengendalian hama dan penyakit utama tanaman cabai di Desa Sungai Geringging Kecamatan Kampar Kiri Kabupaten Kampar. Unri Conference Series: Community Engagement 2: 228-233.

https://doi.org/10.31258/unricsce.2.228-233

(C) 2020 Authors

Peer-review under responsibility of the organizing committee of Seminar Nasional Pemberdayaan Masyarakat 2020 


\section{PENDAHULUAN}

Desa Sungai Geringging Kecamatan Kampar Kiri, Kabupaten Kampar, Provinsi Riau. Kondisi umum wilayah Desa Sungai Geringging adalah datar, bergelombang dan produktifitas tanahnya termasuk tinggi sehingga banyak tanaman yang bisa tumbuh dengan subur. Desa Sungai Geringging di Kecamatan Kampar Kiri luas 509 ha, dengan kepadatan penduduk mencapai 6.072 jiwa penduduk, dengan jumlah kepala rumah tangga $1.605 \mathrm{KK}$.

Kegiatan ekonomi desa selama ini masih didominasi oleh sektor pertanian dan perkebunan. Mengingat wilayah Desa Sungai Geringging $11 \%$ persawahan dan yang $82 \%$ perkebunan yang merupakan lahan mata pencaharian masyarakat. Masyarakat umumnya sudah aktif mengolah lahan pertanian dengan menanam padi, bawang merah dan cabai menggunakan cara yang sudah cukup baik. Namun hasil panen belum seutuhnya menemukan harga yang sebanding dengan pekerjaan tersebut. Kendalanya yang utama adalah naik turunnya harga perdagangan tanaman cabaii terutama pada saat panen raya, yang sering turun drastis sementara harga tinggi kadang-kadang tidak mampu bertahan lama sehingga banyak yang belum sempat menjual sudah turun harga lagi. Sementara petani dihadapkan oleh masalah hama dan penyakit yang seringkali dapat menurunkan hasil panen dan masih rendahnya pengetahuan dalam pengendaliannya.

Tingkat pendidikan petani yang rendah dan pengetahuan petani tentang hama dan penyakit yang menyerang tanaman cabai begitupun pengendalianya masih sangat kurang, sehingga sering mengalami gagal panen karena serangan hama dan penyakit khususnya penyakit virus yang dibawa oleh vektor kutu daun. Oleh karena itu penyuluhan tentang pengenalan dan pengendalian hama dan penyakit yang menyerang cabai adalah sangat penting untuk mencegah kegagalan penanaman cabai pada tahun yang lalu.

Tanaman cabai merupakan salah satu komoditi andalan hortikultura di Desa Sungai Geringging yang mempunyai nilai ekonomis. Kendala utama dalam pencapaian kuantitas dan kualitas produksi cabai (Capsicum annum) adalah gangguan hama dan penyakit yang menyerang tanaman cabai. Dari pengalaman petani tanaman cabai memiliki resiko gagal panen yang tinggi, karena sangat rentan terserang hama dan penyakit. Hal ini dapat merugikan petani secara ekonomi. Kegagalan panen dapat terjadi bila tanaman cabai terserang penyakit virus yang dibawa oleh hama vektor virus.

Jenis-jenis hama yang menyerang tanaman cabai umumnya adalah jenis kutu kebul (Bemisia tabaci), kutu daun (Myzus persicae, Aphis gossypii), Thrips (Thrips parvispinus), Tungau (Polyphagus tarsonemus), lalat buah (Bactrocera sp.), ulat buah (Heliothis armigera) hama pengorok daun huidobrensis), dan ulat grayak (Spodoptera litura). Jenis hama kutu, thrips sp dan tungau (Polyphagus tarsonemus) yang memindahkan penyakit virus kuning / gemini virus, potato leaf roll virus (PLRV), Virus mosaik keriting PVY, CMV, CVMV, virus mosaik, Tobacco mosaik Virus,Virus Kerupuk. Penyakit lain yang menyerang cabai adalah antraknose (Colletotricum spp), bercak daun (Cercospora sp. dan Phytophthora capsici), layu bakteri Ralstonia solanacearum, layu Fusarium oxysporum, bercak bakteri Xanthomonas campestris dan bengkak akar Meloidogyne sp. (Pracaya, 2008; Hussain dan Abid, 2011; Gumbek, 2011). Penyakit terutama virus sangat dikawatirkan oleh petani cabai di Kabupaten Kampar, karena dapat menyebabkan buah cabai kecil-kecil bahkan tidak menghasilkan sama sekali. Penyebaran virus tidak bisa dikontrol karena disebarkan oleh hama kutu. Hama dan penyakit tersebut berpotensi besar menurunkan kualitas dan kuantitas buah cabai.

Kutu daun Aphis gossypii berwarna kuning kehijauan atau kemerahan, nimfa dan imago mempunyai antena relatif panjang, kira-kira sepanjang tubuhnya. Panjang tubuh $\pm 2 \mathrm{~mm}$, tubuh lunak seperti buah pir. Serangga bersayap berwarna hitam berukuran 2-2,5 mm, yang tidak bersayap berwarna merah, kuning atau hijau berukuran 1,6-2,3 mm. Kutu A. gossypii menyerang daun cabai menyebabkan daun mengeriting ke bawah, berkeriput dan bila yang terserang tanaman muda, tanaman menjadi kerdil. Kutu daun ini mengeluarkan embun madu yang menyebabkan tumbuh cendawan jelaga, warna menjadi hitam daan mengurangi asimilasi karbon. Kutu ini juga dapat menularkan 50 jenis virus. Kutu daun Myzus persicae berperan sebagai vektor penyakit virus Potato Leaf Roll Virus (PLRV) dan Potato Virus Y (PVY) (Parcaya, 2003). Serangan hama kutu kebul (Bemisia tabaci) menyerang bagian daun dengan cara menghisap cairan yang ada pada daun dan menularkan virus Cowpea Mild Mottle Virus (CPMMV), virus gemini, virus mosaic dan virus penyakit kuning, sehingga tanaman akan terhambat pertumbuhannya cenderung kerdil, keriting, menguning, tunas dan cabang tidak berkembang dan tanaman produktivitas menurun bahkan gagal panen (Hendrival et al., 2011).

Lalat buah (Batrocera spp.) termasuk hama perusak utama tanaman buah- buahan. Lalat buah merusak dengan cara memasukkan telur pada buah selama 3 hari, telur akan menetas menjadi larva dan memakan daging buah sehingga menjadi busuk. Larva (belatung) lalat buah berada di dalam buah selama 2 minggu 
kemudian berubah menjadi pupa di tanah. Pupa berubah menjadi imago yang siap kawin dan dapat meletakkan telur di buah yang segar lagi. Gejala serangan lalat buah yaitu pada buah terjadi perubahan warna, lunak dan membusuk, dibelah terdapat belatung-belatung kecil dan buah gugur sebelum masak (Suputa et al., 2006; Departemen Pertanian, 2007).

Tindakan pengendalian lebih diarahkan kepada penerapan pengendalian hama terpadu (PHT) yaitu mengkombinasikan beberapa komponen teknologi yang sinergis, seperti pemanfaatan musuh alami famili Coccinellidae dan melaksanakan pengelolaan terpadu kebun jeruk sehat (PTKJS) secara berkelompok. Musuh alami terutama predator yang banyak sekali memangsa kutu yaitu Curinus coerulus Mulsant, Coccinella repanda, C. Transversalis F., lalat famili Syrphidae, Chysomelidae, dan Lycosidae. Predator yang paling banyak ditemukan famili Coccinellidae dan Formicidae yaitu Orcus chalybeus dan Rhizobius lophanta memangsa kutu sisik, Menochilus secmaculatus memangsa Aphis sp. (Dwiastuti et al., 2004; Alviantono dan Leksono, 2011; Mulyani, 2015).

Beberapa permasalahan yang dapat dirumuskan berkaitan dengan analisis situasi di atas yaitu pemahaman petani tentang hama dan penyakit cabai dan cara pengendaliannya dirasa sangat perlu, oleh karena itu perlu dilakukan penyuluhan tentang pengenalan dan pengendalian hama dan penyakit cabai, sehingga petani cabai di desa Sungai Geringging dapat mengenal jenis-jenis hama dan penyakit yang menyerang dan dapat mengendalikan sendiri terutama dengan cara pengendalian secara alami, penggunaan pestisida nabati dan petisida sintetik sebagai alternatif terakhir sesuai konsep pengendalian hama terpadu (PHT).

Pengabdian ini bertujuan untuk memberikan pengetahuan kepada para petani di Desa Sungai Geringging tentang jenis hama dan penyakit yang menyerang cabai, gejala serangan, faktor-faktor yang mempengaruhi dan teknik pengendaliannya.Sasaran penyuluhan ini adalah terutama petani cabai dan petani yang berminat menanam cabai di Desa Sungai Geringging dan sekitarnya.

\section{METODE PENERAPAN}

Penyuluhan tentang pengendalian hama dan penyakit tanaman cabai di Desa Sei Geringging yang dilaksanakan dengan dua metoda. Pertama metode penyuluhan menggunakan media power point, dipaparkan dengan gambar hama, siklus hidup, kerusakan, beserta penjelasakan teknik pengendaliannya. Kedua diskusi dan tanya jawab tentang hama dan penyakit tanaman cabai serta teknik pengendaliannya. Ketiga metode demonstraksi berupa praktek teknik pengendalian yang terdiri dari pertama memperkenalkan pembuatan perangkap metil eugenol untuk mengendalikan lalat buah, kedua perangkap glumon untuk mengendalikan lalat buah, kutu, dan hama lainnya, dan ketiga cara pembuatan pestisida nabati daun sirih hutan. Keempat Praktek lapangan langsung di tanaman cabai berupa pengenalan hama dan penyakit tanaman cabai, gejala serangannya, serta pengenalan jenis-jenis musuh alami hama cabai.

Alat ukur pencapaian tujuan pengabdian adalah pemahaman dan pengetahuan petani tentang hama dan penyakit tanaman cabai, pemahaman dan pengatauan petani tentang pengendalian hama, perubahan pandangan petani tentang pengendalian hama tidak lagi mengutamakan pemakaian pestisida sintetik, dan dapat diatasi masalah hama dan penyakit pada budidaya yang dilakukan.

\section{HASIL DAN KETERCAPAIAN}

Pengabdian masyarakat di Desa Sei Geringging Kecamatan Kampar Kiri Kabupaten Kampar tentang pengendalian hama dan penyakit tanaman cabai (Gambar 1) kegiatan meliputi penyuluhan dan demonstrasi. Penyuluhan menyajikan tentang jenis-jenis hama dan penyakit yang menyerang tanaman cabai, dan teknik pengendalian yang diterapkan terhadap masing-masing jenis hama dan penyakit tersebut. 


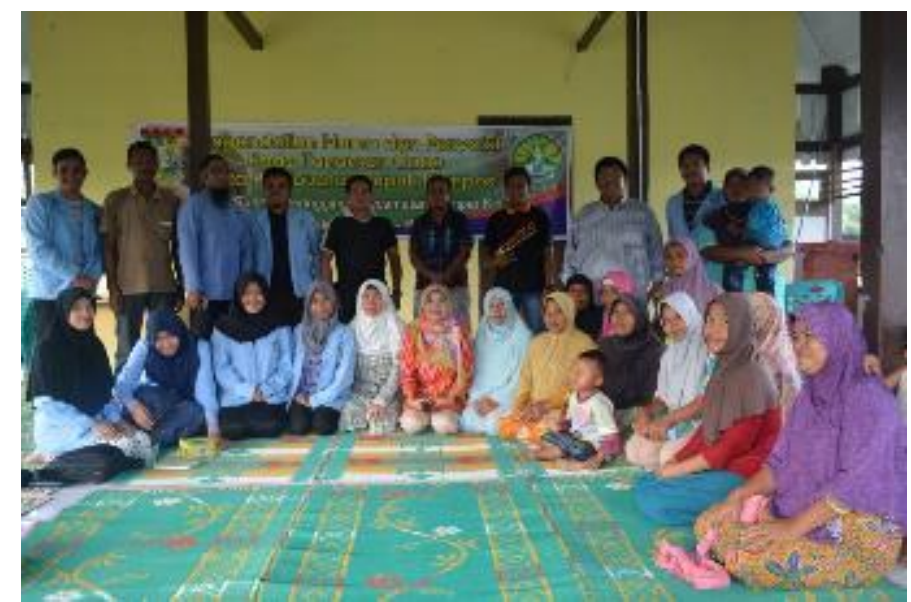

Gambar 1. Kelompok pengabdian Desa Sei Geringging, petani peserta dan mahasiswa kukerta

Pemaparan materi jenis hama dan penyakit disajikan dengan laptop dan infocus yang dipaparkan adalah jenis-jenis hama, siklus hidup dalam bentuk gambar hamanya, dan teknik-teknik pengendaliannya. Satu jenis hama dijelaskan, langsung diberi kesempatan kepada petani untuk mengajukan pertanyaan. Selanjutnyanya, masuk ke jenis hama berikutnya dijelaskan lagi, kemudian tanya jawab, dan begitulah seterusnya. Untuk hama kutu yang merupakan vektor penyakit virus pengendalinnya terutama adalah menggunakan musuh alami, karena sangat banyak jenis musuh alami terutama predator yang dapat memangsa hama kutu. Oleh karena itu penyajian materi musuh alami sebagai pengendali kutu dikenalkan dalam bentuk gambar jenis-jenis predator, kemudian cara mengaplikasikannya.

Petani peserta penyuluhan sangat respon terhadap penyuluhan dan demostrasi yang diberikan (Gambar 2), karena materi yang disajikan tentang jenis hama dan penyakit, serta pengendaliannya pada tanaman cabai sangat dibutuhkan oleh petani, karena kendala utama pada budidaya cabai adalah masalah hama dan penyakit, sehingga benar-benar materi yang diharapkan petani, sangat direspon positif dan diterima secara antusias oleh petani jeruk di Desa Sei Geringging, petani banyak mengajukan pertanyaan-pertanyaan terutama tentang teknik pengendaliannya.

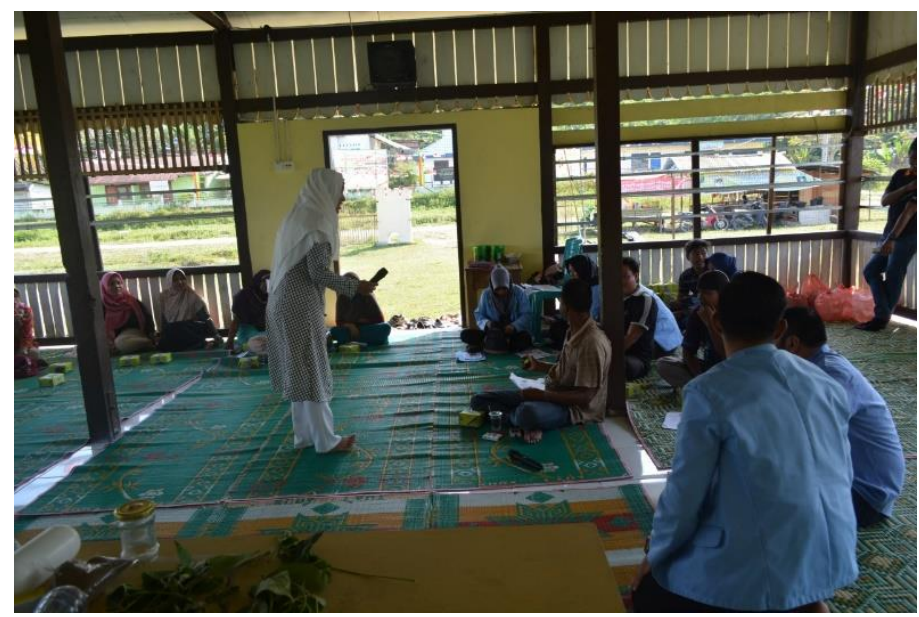

Gambar 2. Penyuluhan dan demostrasi pembuatan pestisida nabati perangkap lalat buah dan perangkap glumon untuk hama kutu daun

Kegiatan pengabdian berupa demonstrasi dilakukan setelah pemaparan menjelaskan materi hama dan pengendaliannya. Teknik-teknik pengendalian di demostrasikan, diperlihatkan teknik pengendalian hama cabai yang telah dipaparkan pada materi penyuluhan.

Demonstrasi pengendalian hama juga tentang pembuatan perangkap glumon untuk mengendalikan hama kutu, lalat buah, thrips, jenis hama lainnya. Glumon (mengandung metil eugenol untuk menarik lalat buah, memberi warna kuning sebagai penarik hama kutu yang suka warna kuning, dan mengandung lem untuk menjerap hama) dioleskan ke dinding botol menggunakan kuas. Perangkap ini digantung dengan tali rafia di dahan tanaman cabai. 
Pembuatan insektisida nabati dari daun sirih hutan untuk mengendalikan jenis-jenis hama dan penyakit tanaman cabai yang banyak terdapat di desa Sei Geringging juga didemostrasikan. Cara pembuatan ekstraknya dan aplikasinya dipraktekan secara langsung diforum.

Demonstrasi pembuatan perangkap metil eugenol, perangkap glumon, dan pembuatan pestisida nabati daun sirih hutan sangat diminati dan direspon baik oleh peserta penyuluhan sehingga terjadi interaksi langsung yang intensif. Petani peserta memperhatikan dengan seksama, banyak bertanya tentang cara aplikasi. Materi yang didemostrasikan belum dikenal dan diterapkan petani pada praktek budidaya tanamannya. Petani hanya mengenal dan menggunakan pengendalian hama dalam praktek budidaya cabai menggunakan pestisida sintetik. Teknik pengendalian yang dikenalkan seperti perangkap metil eugenol dianggap akan mengundang datangnya hama, dan Tim penyuluh bidang hama meluruskan persepsi yang salah tersebut. Petani sangat puas dengan materi pengendalian hama dan penyakit yang disajikan, begitupun teknik pengendalian yang didemostrasikan.

Budidaya tanaman cabai organik diperlukan penggunaan pupuk organik, maka dipraktekan juga pembuatan pupuk kompos. Demonstrasi pembuatan kompos dilaksanakan di lapangan menggunakan bahan sisa tanaman pupuk kandang dan EM 4. Metoda penyuluhan sekaligus demostrasi yang disajikan pada Gambar 3.

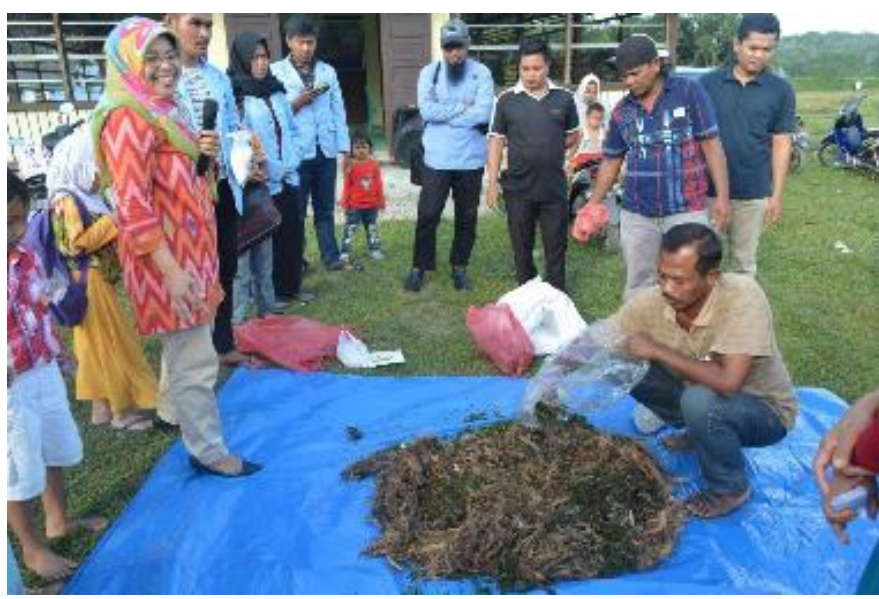

Gambar 3. Demonstrasi pembuatan kompos dari sisa tanaman

Pengabdian dalam bentuk penyuluhan telah terlaksana, petani mendapat pengetahuan pengendalian hama tanaman Cabai. Penyuluhan ini agar dapat diketahui oleh banyak pelaksana pertanian terutama petani cabai. Petani dapat melaksanakan budidaya tanaman secara organik tanpa menggunakan insektisida sintetik. Oleh karena itu penyuluhan kepada petani sangat diperlukan bagaimana petani dapat membudidayakan tanaman cabai dengan menerapkan pengendalian hama dan penyakit secara organik yaitu pengendalan hama tanpa menggunakan insektisida sintetik.

Tingkat ketercapaian tujuan dan sasaran sangatlah besar, bertolak dari ketertarikan petani dari penyuluhan. Topik yang diberikan sangat direspon positif. Dengan demikian pengabdian ini akan berdampak yang signifikan terhadap keberhasilan pembudidayaan tanaman cabai ke depan di Desa Sungai Geringging Kecamatan Kampar Kiri Kabupaten Kampar.

\section{KESIMPULAN}

Program pengabdian pengenalan dan pengendalian hama tanaman cabai sangat penting bagi petani sebagai penunjang utama dalam keberhasilan pembudidayan tanaman cabai untuk menghasilan kuantitas dan kualitas cabai yang maksimal. Dengan demikian pengabdian ini akan memberi manfaat besar kepada petani cabai dalam mengendalikan hama dan penyakit pada budidaya cabainya.

\section{UCAPAN TERIMA KASIH}

Penulis mengucapkan terima kasih kepada LPPM atas diterimanya pengabdian ini dan dapat didanai oleh DIPA Universitas Riau anggaran 2017. 


\section{DAFTAR PUSTAKA}

Alviantono, R. dan A.S. Leksono. 2011. Keragaman Serangga Musuh Alami Kutu Sisik Lepidosaphes beckii pada Jeruk Keprok dan Jeruk Manis. Jurnal Biotropika. 1(1), 48-52.

Departemen Pertanian. 2007. Pengenalan Lalat Buah. Direktorat Perlindungan Hortikultura. Jakarta.

Gumbek, M. 2018. Major pests of chili. doa.sarawak.gov.my/web

Hendrival, P. Hidayat, A. Nurmansyah. 2011. Kisaran Inang dan Dinamika Populasi Bemisia tabaci (Gennadius) (Hemiptera; Aleyrodidae) di Pertanaman Cabai. J. HPT Tropika, 11(1), 47-56.

Hussain F, and M.Abid. 2011. Pests and Diseases of chilli crop in Pakistan: A Review. Int. J. Biol. Biotech, 8(2), 325332.

Mulyani, R. 2015. Kelimpahan dan Keanekaragaman Arthopoda Predator serta Artropoda Lainnya pada Tanaman Jeruk di Cikarawang, Kabupaten Bogor. Skripsi. Departemen Proteksi Tanaman. Fakultas Pertanian Institut Pertanian Bogor. 43 hal (Tidak dipublikasikan).

Pracaya. 2003. Jeruk Manis: Varietas, Budidaya dan Pasca Panen. PT. Penebar Swadaya. Jakarta. 160 hal.

--------. 2008. Pengendalian Hama \& Penyakit Tanaman secara Organik. Penerbit Kanisius. Yogyakarta. 308 hal.

Prajnanta, F. 2003. Agribisnis Cabai Hibrida. Penebar Swadaya. Jakarta.

Reddy, Setiadi. 2001. Bertanam Cabai. Penebar Swadaya. Jakarta.

Suputa, Cahyanti, A. Kustaryati, M. Railan, U.H. Issusilaningtyas dan W. Mardiansih. 2006. Pedoman Identifikasi Lalat Buah. Yogyakarta. UGM. 27 hal. 